Helena Markowska-Fulara

Uniwersytet Warszawski*

iD hteps://orcid.org/0000-0003-1219-3084

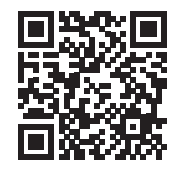

\title{
On Didactic Poetry. The Criterion of Purpose as the Principle of Generic Classification in Polish Classicistic Poetics
}

\begin{abstract}
The article is dedicated to the category of purpose as a criterion for distinguishing literary types and kinds in early 19th-century Polish poetics. The author discusses this topic on the basis of treatises (by E. Słowacki, J.F. Królikowski, and J. Korzeniowski) which apply a two-tier division of poetry into types and genres. She analyses three issues: distinguishing didactic poetry as a type of literature; the general criteria for literary typology; and the distinction between poetry and rhetoric. As a point of reference, the author refers to the claims and ideas of S. Skwarczyńska, whose diagnosis concerning the 'popular poetics' of the period between the two world wars confirms the durability of classicistic genological categories.
\end{abstract}


* Instytut Literatury Polskiej Uniwersytetu Warszawskiego

Krakowskie Przedmieście 26/28, 00-927 Warszawa

e-mail:h.markowskafulara@gmail.com

Paper presented as a part of Project no 2017/27/N/HS2/00395 "In Search of the Language. The Birth of Polish Literary Studies in the Context of European Ideological Changes (1795-1830)" funded by the National Science Centre, Poland. 
Divisions and classifications do not enjoy a good reputation in the humanities. This may be why discussions of literary genres - always blamed for attempts to introduce a system, order or impose limitations - appear to be 'unpopular' today (Culler 2009: 897) and are accompanied by an array of criticism levelled at 'generic' thinking ${ }^{1}$. Classicistic genology has a particularly bad press, and is considered passé at best ${ }^{2}$. If we agree that " $[\mathrm{g}]$ enre study itself has undergone changes from Plato's and Aristotle's view of poetry and tragedy to genre as essential classifications to speech genres of everyday life" (Cohen 2003: 5), then the period of Classicism is most representative of the past treatment of "genre as essential classifications."

And still the historical character of classicistic concepts (which were presented in Polish writings in their best developed form in the early 19th century) need not mean that they are irrelevant to later literary studies, including the present day; not does the genology of that period fully reflect the image of a rigid and essentialist classification. Both charges can be refuted by comparing 19th-century poetics with the works of Stefania Skwarczyńska written more than a hundred years later, which not only prove the lasting value of classicistic categories (as observed by that scholar), but also the less obvious durability of the problems addressed in the poetics of that period, later discussed in Skwarczyńska's publications, which were seminal to 20th-century Polish genology as well.

Ever since the Antiquity, European tradition has looked for general criteria of classifying literary works. Such principles were derived, among others, from Aristotle's Poetics, where he lists three criteria for classifying mimetic arts: the media, objects and modes of mimesis. The first of these makes it possible to distinguish the arts practised by poets (whose medium is the word), while the other two criteria divide their works into those representing people as better, worse or the same as in real life, and into those using narration or direct presentation

1 This is, for instance, how the topic of genres is approached in the PMLA issue dedicated to this subject, whose introduction nearly opens with 'antigeneric' quotes from Croce and Derrida (Dimock 2007: 1377).

2 Joseph Farrell thus begins his reflections on ancient genology in another special magazine issue:

It was once believed that the ancients invented and perfected certain genres and that the works they left might serve as models for later writers. Today belief in ideal patterns is a distant memory, and our interest in genre takes other forms. (Farrell 2003: 383) 
(Aristotle ed. 1995: 29-35) ${ }^{3}$. We will return to the Aristotelian tradition later, as it is of key importance to classicistic poetics. For now may it suffice to observe that, though the Poetics does contain some reflections on poetry's purpose (in the remarks on the pleasure of imitating and in pointing to plot as the aim of tragedy, because it is the experience of the plot that brings about the katharsis), Artistotle's text does not present a sufficient variety of aims that might be used as the basis for a classification of literary works.

Rudiments of such a classification can be found in the writings of two Latin-language authors important to literary studies in the modern era: namely, Horace and Quintilian. The former writes in his Epistula ad Pisones (Ars Poetica): "aut prodesse volunt aut delectare poetae" (v. 333) $)^{4}$. The latter (in Book X of his Institutio Oratoria) lists three aims of the speaker: docere, movere, delectare (3.5.2) ${ }^{5}$. Neither in Horace nor in Quintilian did these types of creative action serve as a criterion for distinguishing various categories of writing, not to mention literary kinds or genres. All the same, the aims of poetry and rhetoric — which they signalled succinctly - were quoted later in history not just to define the writer's or speaker's aims, but also to distinguish a certain problematic type of poetry — namely, the didactic one.

\section{The Fourth Type}

It was Stefania Skwarczyńska who pointed to the problematic nature of this type of poetry in the paper (seminal to her genological theory) entitled Opojecie literatury stosowanej [Toward the Concept of Applied Literature] (Skwarczyńska 1931). Skwarczyńska relates herself to the division of literature into epic, lyric and dramatic - reinforced in Romanticism and variously justified in the 19th and 20th centuries. She starts her argumentation in favour of the notion of applied literature being introduced in scientific discourse by observing that popular poetics also distinguishes a fourth type - that of didactic poetry. It was this 'illegitimate' type that disturbed the neat tripartite scheme and became a point of departure first for introducing the postulated notion, and subsequently (in Wstęp do nauki o literaturze [Introduction to Literary Studies]) - for a new four-part classification based on the criterion of the function of a given type of artistic utterance [Skwarczyńska 1965: 116]. As Skwarczyńska herself pointed out, early 20th-century school poetics did not invent this new 'didactic' type, but rather they continued a much older, predominantly 18 th-century tradition:

It is especially the popular aesthetics that upholds the variety of divisions used by Renaissance theorists, combining them with the approach characteristic of the 18th century, namely, that of allotting the various kinds of literature to a greater number of categories, and specifically, to the category of didactic poetry as one possessing an equal status to the epic, lyric and dramatic. One might even claim that popular theory accepted this four-part division as its basis. (Skwarczyńska 1931:2)

The 'popular' genology characterised in this quotation proves to be surprisingly close to Polish genology of the late Classicism - not only in that the latter consistently distinguished the 'type of didactic poetry'. Early 19th-century genology also shares with Skwarczyńska's

3 In the case of editions of ancient authors and of posthumous publications, the abbreviation 'ed.' reminds the reader that the date given is not the one of writing the text, which is frequently hard to establish with any precision.

4 "Poets aim to either benefit, or to amuse" (Horace ed. 2005: 479).

5 “[...] Instruct, move and charm" (Quintilian ed. 2001:396). 
work the overlap of two inspirations: the one-level division (into types of equal status) derived from the Old Polish tradition (or, more generally, from Latin-language poetics of the Renaissance and the Baroque) and the two-level classification (featuring several general 'categories', within which various genres are subsequently distinguished). The terminology of the era is unstable in this respect, since it does not recognise the difference between kind and genre, and labels the upper-tier categories variously as 'sections' (Pol.oddziaty) or 'classes' (19th c. Pol. klassy) ${ }^{6}$.

In his analyses of the genological awareness of the period as reflected in the treatises of Polish theorists, Piotr Żbikowski distinguishes three phases (1999: 212): starting with an exclusive one-tier model, to various heterogeneous approaches that (as in Ludwik Osiński's lectures) listed the suprageneric categories of dramatic and lyric poetry side by side with the idyll, satire and fable (Osiński ed. 1861), to a full two-tier system. These 'phases' should probably not be considered as chronological stages, since Euzebiusz Słowacki's consistent two-tier model as presented in his $O$ poezji [On Poetry] is several years older than Osiński's lectures in which the two types of division still overlapped. It seems that the transition to a consistently hierarchical, two-tier classification in that period was at least partly responsible for the problems observed a hundred years later by Skwarczyńska, which also involved listing didactic poetry (commonly distinguished as a type in the early 19th century) in handbooks. The scholar described the approach of Romantic and later theories of literary kinds to this category as "the partridge policy" (Skwarczyńska 1931: 2).

In order to reconstruct the criteria which determined the classification of poetry by early 19 th-century theorists, and especially the question whether the function or aim of literary utterance was taken into account by those authors - we should look at the category of 'didactic poetry' as the element that differentiates those early theories from later thought. In doing so, we will also to some extent follow Skwarczyńska, who, having noted that this type of writing is disinguished from the other traditional types by its function, introduced the notion of 'applied literature' in theoretical thought. While looking for criteria of generic classification, we must focus on treatises that make up the third phase of the development of classicistic genology, characterised by a two-tier division. One of those treatises is Euzebiusz Stowacki's On Poetry, in which he writes:

when a poet comprehends with his mind certain truths pertaining to customs, arts or abilities, and when the import and significance of these truths are such as to greatly preoccupy his imagination and inspire poetic fervour in him - he then extols them in his poems, and the kind of poetry he creates in this manner is what 'we call didactic or educational. Beauty and pleasure should be combined with benefit in every kind of poetry, but in this kind in particular, the rhyming author strives to ensure that the truths he has announced, adorned with all the graces of poetry, may, by entertaining the readers, also become useful teaching to them. (Słowacki ed. 1826: 87-88)

6 Genological terminology is problematic already on its basic level, especially in translation. Polish tradition uses the terms 'kind' (Pol. rodzaj) and 'genre' (Pol. gatunek), which refer to Aristotle's logical differentiation between genus and species, describing two levels of the classification of literary works. Stefania Skwarczyńska, however, applies the terms $d z i a t$ ('type', an upper-tier category) and rodzaj ('kind', here in the sense of a lowertier category, equivalent to today's genre or gatunek). In classicistic poetics, all these terms are used interchangeably and imprecisely. In English-language tradition, the term genre is normally applied both to literary kinds and genres. 
To Słowacki, the key distinguishing quality of didactic poetry is its subject ("truths pertaining to customs, arts or abilities"). In second place, he notes an element of (educational) benefit, which is inseparable from this kind of poetry. He recalls the Enlightenment-age formula of 'teaching through entertainment', and points to teaching as the constitutive element of 'educational' poetry. He also mentions the poet, who should have this purpose in mind.

Two other authors, Franciszek Królikowski and Józef Korzeniowski, take up the second part of Słowacki’s definition. Królikowski writes:

Teaching reason, along with vivid application of the imagination and emotions, are the two main aims of poetry. A [type of] work in which the latter element is but an adjunct of the former, is called didactic poetry. (Królikowski 1828: 33)

Korzeniowski defines didactic poetry in an analogical manner:

Poetry has two main aims: Teaching reason, and providing a vivid preoccupation for imagination and feelings. Poetry that excels in the former, while the latter only serves as an adjunct and to enhance the experience - is called educational or didacting poetry. (Korzeniowski 1829: 295)

The close similarity between both definitions results from this passage being a near-literal translation of a corresponding section from a handbook by Johann Joachim Eschenburg, entitled Entwurf einer Theorie und Literatur der Schónen Wissenschaften (1783: 89), which was popular among Polish literary scholars in that period. Importantly, with respect to the overall division of poetry, Polish theorists do not follow Eschenburg, who only distinguished two kinds: dramatic and epic, and within the latter he spoke of 'educational poetry' (Lehrgedicht). For the Polish authors, however, didactic poetry is one of its five basic kinds.

Definitions of this sort refer to the category of purpose or aim. The two aims mentioned here ('teaching' and 'vivid preoccupation') are in fact the Horatian objectives of benefit and amusement, which they borrowed via the German theorist and modernised by referring to 'reason' as well as 'imagination and emotions'. Among Polish authors, it was e.g. Franciszek Wężyk who mentioned these aims explicitly when he wrote: "The general aim of dramatic poetry, as well as of poetry's other kinds, was aptly defined by Horace as Aut prodesse volunt, aut delectare poetae" (Wężyk ed. 1878: 280).

All the three theorists claim that the indicator of didactic poetry is the domination of one of two equally indispensable aims. Each poemought to perform both functions, and it is the dominant purpose that decides about its generic attribution.

\section{The Principles of Division}

Authors of poetics clearly defined the type of didactic poetry by reference to its purpose, or rather - to the domination of one of the aims over the other. But was the same criterion used to distinguish the other literary kinds? Słowacki was, as we remember, chronologically the first to mention the subject of poetry in the first place in his definition, only followed in the second place by the aim that the author sets for him- or herself. This was a consequence of the genological classification that he adopted, based, in general, on the criterion of poetry's subject: 
The subject of poetry is, therefore, either the poet himself, or the things that surround him. In the former case, he either explains his emotions and sentiments or presents the observations and remarks that come from his reason. Hence the first two forms: lyric and didactic. In the latter case, the subject of poetry is some affair, in other words - action [...]. Human affairs or actions can either take place in the past or be staged as present events. Descriptions of affairs that took place at some time in the past belong to the epic or narrative form, while staging such affairs as though they were present events belongs to the dramatic form. (Słowacki ed. 1826: 63)

Królikowski was the second to list a number of possible criteria for the division into kinds or types, in succession: the form of presentation; those of the poet's spiritual powers that were particularly intensely employed for the composition of a given work; the presented subject (Królikowski 1828: IX-XII). Eventually, however, he adopts a division "in accordance to the poet's purpose," because, he claims, it is "less sophisticated, but perhaps simpler and more natural" (Królikowski 1828: XII). Thus, the poet either "directly expresses emotions" or "tells a story and describes in order to educate," or "directly represents the objects through narration and description," or "introduces acting persons," or, finally, "introduces persons who, alien to reason, only following their emotional urges, which took hold of their souls, act and can also express themselves lyrically" (Królikowski 1828: XIII). The latter peculiar type, distinguished most likely in connection with the importance of 'emotions' in Królikowski's entire poetics - is lyric-dramatic poetry, while the other four types might be identified as lyric, didactic, epic and dramatic. This classification combines in fact two different criteria: those of purpose and the way of presentation. The latter is the condition for distinguishing dramatic poetry, which "introduces acting persons," as a separate type. Słowacki makes a similar exception for drama, applying - though not directly — the criterion of manner of imitation rather than subject. The dramatic type, he claims, not so much represents "present affairs" as affairs that are "staged as present" or "as though they were present events."

The resulting classifications are nearly identical, but Królikowski’s poetics was the only one in his era that directly declared 'purpose' as the criterion of its generic classifications. Let us note that in Królikowski's model this 'purpose' was strictly related to the person of the poet, and to his or her activity - which brings it close to Skwarczyńska's later concepts presented in her Introduction to Literary Studies, referring to the sender's field of activity. According to her findings, the senders and the subject are those fields whose "modifications most clearly organise generic structures (Skwarczyńska 1965: 121). This approach makes it possible to interpret the similarity of both resulting classifications, since both theorists seem to point to the same generic structures, but discuss them from different perspectives.

All the three possibilities of classification listed here: in terms of subject, form (manner of imitation), and the poet's purpose (aim) — are combined in the last of the three fully-fledged two-tier classicistic genologies, the one presented by Józef Korzeniowski, who explains that "[f]or this division, we need to take into account both the subject and the form that the poet puts it in" (1829: 72). Rather traditionally, he signals that his classification is to refer to both the content and the form of the literary work. As a result, he arrives at the following classification: a) lyric poetry, in which "the poet pours out his or her emotions;" b) narrative poetry - in which he or she "retells events and deeds;"c) dramatic poetry, in which "events are represented to our eyes in the form of actions;" d) didactic poetry, where "the poet educates and describes useful subjects, and e) minor forms, in which "the poet demonstrates his wit" (Korzeniowski 1829: 72-73). The reference to form, which he signalled, comes — as in 
the other two models presented above - in the context of drama. Definitions of the other types focus, as in Królikowski, on the person of the poet and his or her actions, thus incorporating - though not explicitly - the category of the author's purpose. The last, fifth type, in which "the poet demonstrates his wit" (unfortunately not dealt with in more detail) comprises epigrams and bagatelles (Pol. fraszki), and seems to be the unique example of a literary kind performing an autotelic function.

The transition from multi-part to two-tier models led, therefore, to the appearance in the poetics published in the 1820 s of a four-part division into types, while the fifth type mentioned in those texts is clearly auxiliary and testifies to the difficulty of incorporating all the poetic material in the first four types. Słowacki frankly calls this fifth category 'the complementary forms', in other words - sets that could just as well be labelled 'others' or 'the remaining ones'. In Królikowski's model, the fifth type is a combination of two others. Possibly the most interesting option is the proposal of distinguishing 'minor forms' as a kind of display of the poet's abilities. Though each of the authors discussed above points to a different principle of classification, eventually they all refer to the same criteria, in particular - to the division with respect to 'form' or manner of imitation in the case of the epic and drama (as in Aristotle), and to the criterion of purpose in the case of didactic poetry, which aims at (educational) benefit first, and pleasure only in second place.

\section{Outside Poetry?}

The incorporation of didactic poetry as a separate type in all the listed classification does not mean that this type did not provoke any theoretical controversies. Its inclusion among poetic kinds ought to be considered in the context of the distinction between poetry and rhetoric. This distinction led to terminological problems discussed a hundred years later by Skwarczyńska:

The classification models usually apply the term 'poetry'; thus they discuss the division of poetry, and the types of epic, lyric, dramatic and didactic poetry. The notion of 'poetry' was used without regard for its definition and independently of the distinction between poetry and prose. Thus the novel was officially included in the category of epic poetry according to this model, while farce was a genre of dramatic poetry, though they were not poetry in the strict sense of the word, neither with regard to form or content. In popular literary theory (which was fed to students at school), poetry was then opposed to prose, which led to utmost confusion. Prose was to include such subtypes as historical, rhetorical prose, etc., while the novel was a genre within poetry. Still, the approach to content (factual or fictitious) was not decisive in this classification, as evident from including the didactic type in poetry instead of allotting it to 'sober' prose. (Skwarczyńska 1931:20-21)

In the early 19th century, the distinction between poetry and prose was in fact synonymous with the division between poetry and the art of rhetoric. It was in that period that the tensions observed a hundred years later began to grow. Poetics began to include such genres as the novel or romance, described in detail by Korzeniowski, who points to its close affinity to the epic (Korzeniowski 1829: 199). Its prosaic form cannot obliterate the fundamental distinction, usually defined by the opposition of truth (rhetoric) and probability (poetry) or by pointing to the special role of emotions in poetry. None of these divisions was identical with the distinction between poetic and prosaic type of speech. The warning that poetry is not simply composing in verse was one of the loci communes of treatises in that period. Impor- 
tantly, some authors referred to the criterion of purpose as the principle of division between the two arts. Królikowski wrote: "The last and highest aim of all poetic works is to provide pleasure [...] conversely, the aim of rhetoric is to teach" (Królikowski 1828: 8). Both the latter criterion and the reference to the category of truth must have led to controversies concerning the inclusion of didactic poems in the general category of poetry.

Korzeniowski points to the opposition between truth and fiction ('invented tales') as the foundation for defining poetry, and thus undermines the notion of didactic 'poetry':

Owing to an erroneous concept of truth and fiction in poetry, such texts were denied their place among poetic works. But a didactic poem ought to be a poem not only in some of its parts, but also as a whole, and thus differ from systematic prosaic teaching, not only in its external form, but in the entire method by means of which the poet presents the truths and principles. (Korzeniowski 1829: 304)

At this point, the Polish theorist echoes Eschenburg's argument (1783: 90), and so does Słowacki, who does not mention 'fiction', but explains more precisely what 'notion of truth' places didactic poems outside the scope of poetry:

There are some who exclude didactic poems from the list of poetic genres, based on the fact that declaring truth and science belongs essentially to the realm of prose. But a didactic poem differs from prose not only in its external ingredients, but in its internal make-up and spirit as well. (Słowacki ed. 1826: 88)

Truth is thus the domain of prose (and rhetoric), whilst fiction - that of poetry. The authors then attempt to specify what 'method' or 'internal make-up and spirit' make it possible to include didactic poems in the category of poetry. Królikowski's explanation seems to be the clearest one (while his reasons for excluding didactic poems from the category of poetry are rather less precise):

Some exclude didactic poems from the domain of poetry and claim that they are not poetry; however, they differ from prosaic, purely skill-oriented teaching not only in their external form, but also essentially in the way in which the poet presents the truths and teachings transformed into emotions as far as possible by means of senses, as well as images, examples, descriptions of character, bestowing on them the poetic form. (Królikowski 1828: 34, emphasis H.M.F.)

Królikowski points to three criteria which make it possible to include the didactic type in the category of poetry: its association with emotions (which are to accompany the presented truths and which, we may conjecture, are to be generated in the reader); its sensual manner of presentation (one of the key postulates of poetics in that era, which called on the artist to present objects in such a way that they worked on the senses, especially on the sense of sight ${ }^{7}$ ) as well as the poetic form (or 'shape') achieved through the presentation of abstract scientific truths by means of concrete images, examples and characters.

'External ingredients,' 'external form,' 'external make-up' - i.e. the versified form - is not the decisive criterion for inclusion in the category of poetry. Nor is the author's purpose the

Euzebiusz Słowacki wrote:

Writers strive to represent the images of things so strikingly and emphatically, to give such vivid colours to things, that the delighted reader can really seem to see the represented object. (Słowacki ed. 1827: 41) 
decisive criterion, though it decides about a given piece belonging to the realm of didactic poetry, but the domination of 'benefit' over 'pleasure' will not suffice to question the poetic nature of didactic poems. The Aristotelian division into history (and, by extension, all prose, submitted to the rules of rhetoric) as presenting true things, and poetry - as dealing with only probable ones (so in a sense 'fictitious') - was applied, but not without exceptions. Apparently there is a way of transmitting truth that can be called poetic, as long as emotions and senses are also applied apart from the recipient's reason. Therefore not only while distinguishing literary kinds or types, but also when allotting individual texts to the domains of either poetry or prose, the principles applied were far from uniform, or rather several criteria were used simultaneously. In the case of didactic poetry, the discrepancy may have resulted from the historical nature of this category, which comprises traditional, wellestablished literary genres. The individual works belonging to those genres, such as Virgil's Georgics, Delille's Les Jardins, Krasicki’s satires, Trembecki's Sofijówka, and Dmochowski's Art of Rhyming - were among the most highly appreciated models, which formed the basis for literary education.

On the other hand, the doubts voiced with regard to the place of didactic poems within the domain of poetry prove that theorists of that period were well aware of the problematic nature of the presented classifications. What is more, their other statements directly point to the fact that at least some of them considered these divisions as an educational necessity rather than the essence of poetry ${ }^{8}$, and they recognised the existence of mixed genres ${ }^{9}$, or even genres represented by only one piece of writing ${ }^{10}$.

The above comparison of the three most consistent early 19 th-century 'classifications of poetry, with special reference to the definitions of didactic poetry which they contain - allows us now to draw some conclusions. To begin with, we can observe how the traditional distinction between poetry and rhetoric was becoming more and more difficult to uphold. The oppositions between poetry and prose, fiction and referentiality (or probability and truth), emotions and reason - do not suffice to uphold the traditional denotations of both terms without reservations (because criteria may often overlap or clash, as in the case of including

8 Królikowski wrote:

While almost no division can be considered truly perfect, a systematic division is undoubtedly necessary in this place in order to grasp, survey and compare the parts of the whole" (Królikowski 1828: XII). Korzeniowski expressed this most emphatically: "From the point of view of common sense, such divisions bring little benefit to art itself, but critics need them to survey works of one genre and poetics need them to present the principles more suited to one genre than another. (Korzeniowski 1829: 72)

9 Słowacki wrote about them:

These four types of poetry could include all rhymed writings if by mixing the initial forms and modifying them for specific purposes we did not arrive at such genres that seem to belong now to one, now to the other class. (Słowacki ed. 1826: 63)

10 A comment to this effect can be found in Osiński’s Wyktad literatury porównawczej [Lectures in Comparative Literature] ego:

Should [Dante] Alighieri's Divine Comedy count strictly as a epic, it would be fitting to begin our explorations with that work. But it is a unique work that constitutes a genre unto itself and had no model in earlier times. Should it inspire any poet in the future with its example to attempt a similar task, it could become the source of the noblest poetry that new literature now looks forward to. (Osiński ed. 1861: 183) 
didactic poems within the domain of poetry). Nor does the criterion of purpose make a precise distinction possible, though we have quoted examples of associating poetry with pleasure and rhetoric with science. Traditionally providing benefit is (along with pleasure) one of the aims of poetry (in accordance with the formula prodesse aut delectare), while rhetoric aims to move and please apart from teaching (as evident from the formula docere, movere, delectare).

Secondly, the criterion of the poet's purpose is pointed to directly as the principle of generic division in Królikowski's classification, and is also actually applied by Korzeniowski. In both cases, this criterion is combined with the principle of division according to the manner of imitation, which makes it possible to distinguish drama from other literary kinds. The criterion of purpose is commonly applied in definitions of didactic poetry, which is distinguished by the domination of teaching over pleasure. It needs to be further examined to what extent the different aims of the individual genres determine the 'principles' ascribed to them as well as the recommendations concerning works written within a given genre.

Thirdly, the 'popular' or 'school-oriented' literary theory in Poland between the two world wars (which Skwarczyńska writes about) seems to have been a direct descendant of the genological handbooks from the 1820s. The task of describing the later, 19th-century developments of this tradition still needs to be taken up, but the similarities (such as the way of using the term 'poetry', the allotment of individual genres to either poetry or prose, the inclusion of didactic poems in the domain of poetry as one of four distinguished types) are too close to be accidental. Late classicistic genology, which initiated the two-tier division into kinds and genres, can therefore be considered as the starting point for the genological problems summarised by Skwarczyńska. It is the more notable that theorists of the period did not omit the 'purpose' of poetry as a possible genological criterion, and even made attempts to turn that purpose into a principle of their classifications.

Their awareness of the multiplicity of possible classifications, their presentations and discussions of genological controversies - proves that, contrary to stereotypes, the pre-Romantic thought on literature did not take genres for granted as natural, arbitrary and unquestionable. The problems which they took up, as well as many of their solutions, have proved durable, which demonstrates the necessity for historical research into the categories of literary studies going far back into the 19 th century. 


\section{Bibliography}

Aristotle (1995), Poetics, ed. and transl. S. Halliwell, Harvard UP, Cambridge (Mass.)-London. Cohen Ralph (2003), Introduction, "New Literary History", vol. 34, no. 2, Theorizing Genres I. Culler Jonathan (2009), Lyric, History, and Genre, "New Literary History", vol. 40, no. 4.

Dimock Wai Chee (2007), Introduction: Genres as Fields of Knowledge, "PMLA", vol. 122, no. 5, Special Topic: Remapping Genre.

Eschenburg Johan Joachim (1783), Entwurf einer Theorie und Literatur der schönen Wissenschaften, Friedrich Nicolai, Berlin-Stettin.

Farrell Joseph (2003), Classical Genre in Theory and Practice, "New Literary History", vol. 34, no. 3, Theorizing Genres II.

Horace (2005), Satires, Epistles and Ars Poetica, transl. H. Rushton Fairclough, Harvard UP, Cambridge (Mass.)-London.

Korzeniowski Józef (1829), Kurs poezji [A Course in Poetry], N. Glücksberg, Warszawa.

Królikowski Józef Franciszek (1828), Rys poetyki wedle przepisów teorii w szczegótach z najznakomitszych autorów czerpanej [An Outline of Poetics, in Accordance with Theoretical Principles Derived in Detail from the Most Eminent Authors], under the editor's imprint, Poznań.

Osiński Ludwik (1861), Wyktad literatury porównawczej [Lectures in Comparative Literature] [in:] idem, Dzieta [Works], vol. 2, under the imprint of the author's widow, Warszawa.

Quintilian (2001), Institutio oratoria, vol. 1, ed. and transl. D.A. Russell, Harvard UP, Cambridge (Mass.)-London.

Skwarczyńska Stefania (1931), O pojęcie literatury stosowanej [Toward the Concept of Applied Literature], "Pamiętnik Literacki", book 1.

- (1965), Wstęp do nauki o literaturze [Introduction to Literary Studies], vol. 3, part 5, Rodzaj literacki [The Literary Kinds], A. Ogólna problematyka genologii [General Problems in Geno$\log$ ], Instytut Wydawniczy PAX, Warszawa.

Słowacki Euzebiusz (1826), O poezji [On Poetry] [in:] idem, Dzieta z pozostatych rękopismów ogtoszone [Works Edited from the Manuscripts Left Bebind by the Author], vol. 2, Józef Zawadzki, Wilno.

- (1827), Teoria smaku $w$ dzietach sztuk pieknych [Theory of Taste in Works of Art] [in:] idem, Dzieta z pozostatych rękopismów ogtoszone [Works Edited from the Manuscripts Left Behind by the Author], vol. 1, Józef Zawadzki, Wilno.

Wężyk Franciszek (1878), O poezji dramatycznej [On Dramatic Poetry], ed. Tomkowicz S., "Archiwum do Dziejów Literatury i Oświaty w Polsce" ["Archive of the History of Literature and Education in Poland"], vol. 1, Akademia Umiejętności, Kraków. 